\title{
Adult Soft Tissue Sarcoma
}

National Cancer Institute

\section{Source}

National Cancer Institute. Adult Soft Tissue Sarcoma. NCI Thesaurus. Code C7707.

Soft tissue sarcoma occurring in adults. 